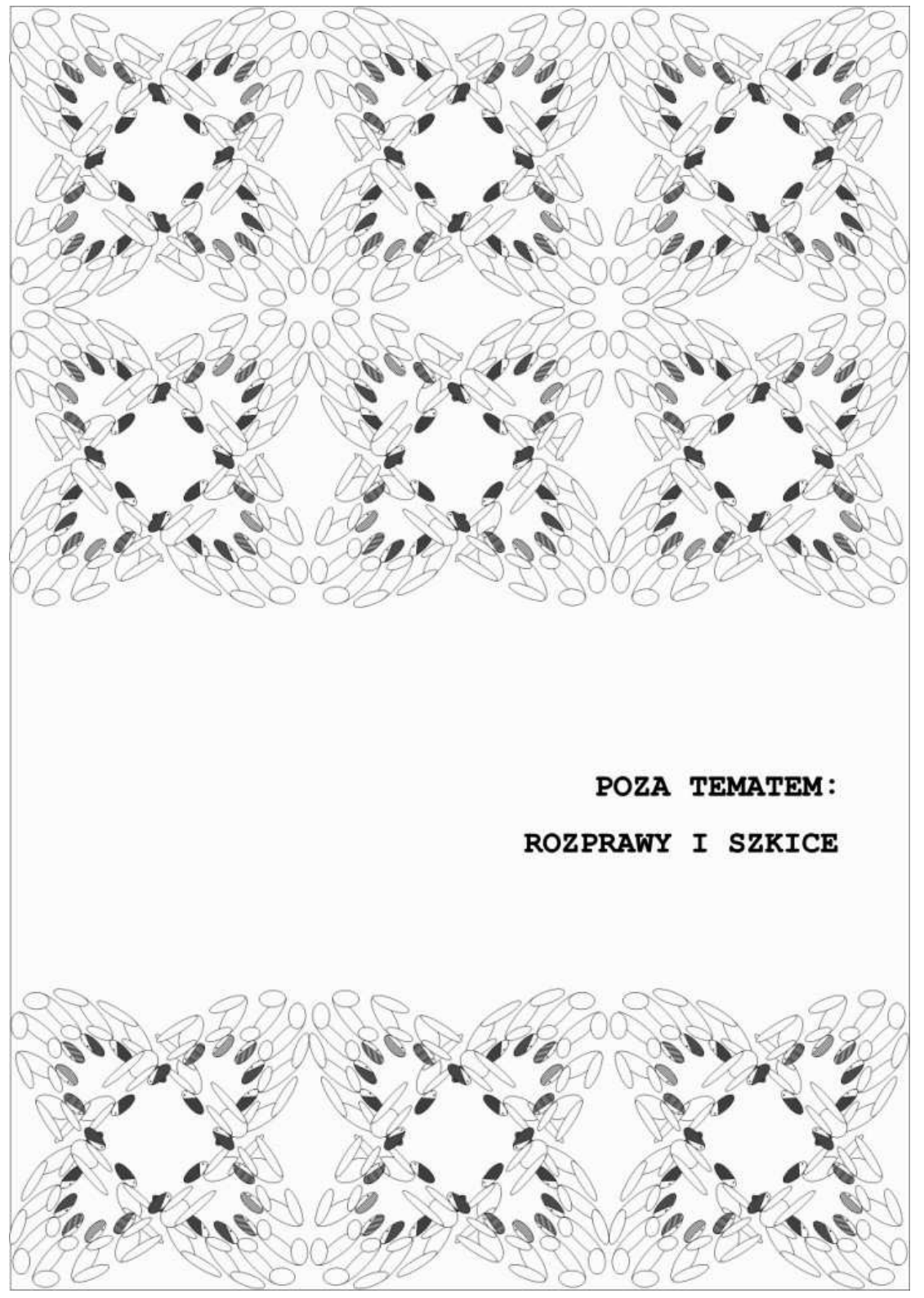





\title{
Lidija Bajuk
}

lidija@ief.hr

\section{Nad Peklom med vodami do Mohokosa, Železne gore i Per(n)jaka}

\begin{abstract}
Bajuk Lidija, Nad „Peklom med vodami” do „Mohokosa”, „Železne gore” $i$ „Per(n)jaka” (Above Pekel med vodami toward Mohokos, Železna gora and Per(n)jak). „Poznańskie Studia Slawistyczne” 3. Poznań 2012. Adam Mickiewicz University Press, pp. 231-245. ISBN 978-83-232-2473-0. ISSN 2084-3011.

I conducted my own ethnographic field research in 1998, 2004 and 2007. Further field research, from 2010 to 2012, under the title 'Folk Piety and the Transmission of Ethnoheritage in Upper Međimurje', was part of Tomo Vinšćak's academic project Sacral Interpretation of Landscape, organized by the Matapur Association and the Ethnological and Anthropological Department of the Faculty of Philosophy in Zagreb. The analysis and comparison of the collected materials has contributed to research into the fascinating and still vibrant - though under-researched - survival strategies of pre-Christian and Christian worldviews in the western and north-western parts of the northernmost districts of Croatia.
\end{abstract}

Keywords: Terra Mater, Veles, witch, Perun, St. Urban, St. Martin, Jarilo, Murai, St. George, water, stone, metal

S poljoprivrednicom Terezijom Farkaš iz Malog Mihaljevca tijekom 1998., 2004. i 2007. razgovarala sam o običajima i obredima njezine i drugih katoličkih seoskih obitelji. Budući da Mali Mihaljevec pripada općini Sv. Juraj na Bregu, obilježavanje katoličkog sveca sv. Jurja na bijelom konju, rimskoga vojnog časnika i kršćanskog mučenika u 4. st. - idealnoga kršćanskog viteza u vrijeme križarskih ratova i gonitelja zmaja - u znaku je velike župne svečanosti.

Općina Sv. Juraj na Bregu nalazi se u Međimurskoj županiji, najsjevernijoj hrvatskoj teritorijalno-upravnoj jedinici. Devet naselja (Brezje, Dragoslavec, Frkanovec, Lopatinec, Mali Mihaljevec, Okrugli Vrh, Pleškovec, Vučetinec, Zasadbreg) obuhvaća i župa Sv. Juraj na Bregu. Na vrhu brijega u Lopatincu ističu se župna crkva i kurija župnog dvora. 
U popisu župa Zagrebačke biskupije crkva sv. Jurja prvi se put spominje 1334. godine. Današnja je crkva, kao i stari župni dvor, izgrađena 1740. „kao proštenjarska crkva (...), pod titulom Majke Božje Loretske, pokraj stare crkve sv. Jurja koja je bila $50 \mathrm{~m}$ sjevernije od sadašnje"1. Jedna je od najljepših baroknih crkava sjeverne i sjeverozapadne Hrvatske, vidljiva žiteljima većeg dijela Međimurja. Župnik Ivan Mihanović u župnoj je spomenici početkom 18. st. na latinskom zabilježio da je nedaleko od stare crkve okružena s pet lipa ${ }^{2}$ visjela kišom i vjetrom uništena slika Majke Božje oko koje su vjernici više puta uočili svjetlost. Zbog toga je župnik odlučio podići pil. No sljedećeg jutra na mjestu predviđenom za poklonac dočekali su ga zacrtani temelji kapele. Gradnju kapele sv. Marije Loretske i štovanje slike Majke Božje odobrio je onodobni zagrebački biskup. Hodočasnici su proširili glas o čudesnim ozdravljenjima po zagovoru Majke Božje Loretske. U drugoj polovici 18. st. kip sv. Jurja premješten je iz starije crkve na glavni oltar, iznad slike Majke Božje Loretske, posvećene 1774. godine. Krajem stoljeća crkva je ukrašena freskama Rangerove škole. Unutar cinktora pronađeni su kosturni ukopi iz 14. i 15. st. Tijekom obaju svjetskih ratova Međimurci i Prekmurci hodočašćenja u Mariju Bistricu zamijenili su hodočašćima u crkvu sv. Jurja na Bregu koju su zvali i crkvom sv. Jurja u Jezerima, odnosno crkvom sv. Jurja na Vodama, prozvanom tako po izvoru vode ispod crkvenog olta$\mathrm{ra}^{3}$. Danas se župna proštenja održavaju na duhovske blagdane - 23.IV. u znak župnog zaštitnika te na blagdan Imena Marijina ${ }^{4}$. Blagdan Sv. Jurja u hrvatskim se kajkavskim krajevima do nedavno obilježavao ovjenčavanjem biljem stoke koja se prvi put u godini izvodila na ispašu, umivanjem, ophodima, trubljenjem, pjevanjem i plesanjem kola oko krjesova, pečenjem jaja i gatanjima 5 .

\footnotetext{
${ }^{1}$ F. Gönczi, Međimurje - ljudi, vjerovanja, običaji, Čakovec 1995 [1895], str. 2. I. Kozjak, Poštovani župljani, „Sv. Juraj na Bregu. Općinski list” br. 1, 2008, str. 4.

${ }^{2}$ Stablo lipe ženski je znak u praslavenskoj i znak Djevice Marije u kršćanskoj slici svijeta (T. Vinšćak, Vjerovanja o drveću u Hrvata, Jastrebarsko 2002, str. 136). S njezina vrha na ljetni suncostaj javno su se prozivali budući vjenčani parovi, kraj stabla se palio krijes (kaz. M. Tuksar), a od drveta su se izrađivali kipovi svetaca (kaz. I. Vožar). Cf. popis kazivača.

${ }^{3}$ F. Gönczi, op. cit.

${ }^{4}$ I. Kozjak, op. cit.

${ }^{5}$ M. Gavazzi, Godina dana hrvatskih narodnih običaja, Zagreb 1991, str. 41-57.
} 
Unutrašnjost župne crkve sv. Jurja s oltarnom slikom sv. Jurja na konju koji mačem probada zmiju te raspela u Lopatincu i Malom Mihaljevcu žene i danas ukrašavaju proljetnim biljem. U jurjevsko predvečerje Terezija ograde, vratnice i prozorska okna obiteljske kuće i gospodarskih zgrada kiti zelenilom:

Za Jurjevo gajimo ograde lese brezovim, glogovim i čremsinim kitjem. Brezovu kito tre v zemlu i na senokoše fteknoti i posvetiti jer so tam kače i slepe vuši, slične kačam ${ }^{6}$.

Vodom posvećenom na Sveta tri kralja Terezija prska kuću i nasade radi zaštite od copernica. Danas uzgaja perad, svinje i kućne ljubimce, ali ne više i stoku.

Kouli drevja smo skopali grabe i napunili jih gnojom. F štali smo voužo natezali kaj bo krava bole dojila. Na zemlu smo deli broča od lagva i nutri tepsíjo z žgoncaj za kokoši. Kouli stola smo jejci vu vrečki sonjkali kaj bodo bole jejci nesle: „Ko-ko-dak, ko-ko-dak!”7.

Vjernici se u crkvi na prijepodnevnoj misi mole i ispovijedaju, pa se pojam proščenje pučki tumači kao „godišnje oproštenje”. Pjevaju i jurjevski napjev Na čast svetom Jurju:

Sveti Juraj, vitez mladi, na istoku rođen je, / sigder bil je ljubljen, dragi, kud god negda hodil je. / Od starejših, plemenitih, porođen je na ov svet, / z dobrom peldom i krepostjom odgojen je za ov svet. / Da su otec, majka njegvi iz sveta preminuli, / ves imetek na Juraja sina su izručili. / On pak svoje celo blago od sebe otpustil je, / za vojnika pod zastavu cesarovu stupil je. / Videl cesar: razumnoga sve kreposti imel je, / gde je rođen i odgojen, Juraja ispital je. / Na pitanje se je razmel - začudi se cesar ov, / tak i Juraj je postavljen nad jezero vitezov. / Kak je on bil glasoviti, veren vojnik cesarov, / nikaj menje nej vojuval za krščansku on veru. / Imel je on na pameti Jezuša raspetoga, / bolša je čast njemu dana od cesara svetloga. / Predi kaj je dušu svoju zručil Bogu višnjemu, / spričal se je i oprostil se krivice bližnjemu. / Njegvo telo i zastava v Rimu je zakopana, / kapelica na čast njemu prelepa zazidana. / Onda patron, preljubleni, obrni se z neba k nam, / ki smo denes simo dojšli, blagoslov podeli nam! / Da pak bode nam vumreti, skratiti se onda naj, / kak domačim, tak i stranjskim, isprosi vu nebu raj! ${ }^{8}$.

\footnotetext{
${ }^{6}$ Kaz. T. Farkaš.

${ }^{7}$ Ibidem.

${ }^{8}$ Ibidem.
} 


\section{Zeleni/Sveti Juraj}

U hrvatskoj etnografiji poznata su još neka imena sv. Jurja: sveti Đurađ, sveti Đuro, sveti Vitez, ali i zeleni Juraj, zeleni Đurađ, zeleni Đuro, zeleni Juri, Zelenjak, šantavi Juraj. Jurjevi atributi odnose se na poljoprivredno i stočarsko pretkršćansko božanstvo - mitskog kovača, gospodara bilja, životinja i podzemlja. U Međimurju se ,peti dan u tjednu” nazivao šantavim ili plantavim petkom (kaz. J. i I. Kavran). Šantavost „šepavost” povezana je s kovačkim zanatom božanske obitelji, pri kojem su postupci $\mathrm{s}$ arsenom u proizvodnji i obradi metala izazivali trovanje i trajnu invalidnost kovača 9 .

Jurjevski običajni postupci zaštite od zmija potvrđuju i njenu pretkršćansku povezanost sa zelenim Jurjem. Terezija misli da su zmija i zmaj isto. Poznato je da su zmije starim Slavenima bile svete ${ }^{10}$. Prihvaćanjem kršćanstva zmija je izjednačena s đavolom ili sotonom te s vragom i Velesom $^{11}$, iako se u jednoj mističnoj poemi iz 12. ili 13. st. Isus prikazuje kao zmija na križu ${ }^{12}$.

I proljetni obredno-običajni ophod staroslavenskog boga Jarila povezuje se s majgom i/ili zelenim Jurjem, posječenim okićenim stabalcem ili vrbovim košem kojim je maskiran mladić ophoda. S tim je u vezi Terezijino očekivanje zaštitnog učinka brezinih grančica utaknutih u obrađeno tlo. Prema najnovijim nastojanjima rekonstrukcije starohrvatskog mita, jezikoslovca Radoslava Katičića i etnologa Vitomira Belaja, sukob konjanika sv. Jurja i zmaja/zmije u vezi je s borbom gromovnika i zmije u praindoeuropskom mitu is pobjedom Dobra nad Zlom ${ }^{13}$.

9 A. Durman, Vučedolski Orion i najstariji europski kalendar, Zagreb-Vinkovci -Vukovar 2000; idem, Vučedolski hromi bog: zašto svi metalurški bogovi šepaju, Vukovar 2004.

${ }^{10}$ J. Grbić, Vjerovanja i rituali, u: Hrvatska tradicijska kultura, ur. Z. Vitez, A. Muraj, Zagreb 2001, str. 494.

${ }^{11}$ V. Belaj, Hod kroz godinu, Zagreb 1998, str. 65.

${ }^{12}$ J. Chevalier, A. Gheerbrant, Rječnik simbola, prev. A. Buljan, D. Bućan, F. Vučak et al., Zagreb 1994, str. 803.

${ }^{13}$ V. Belaj, op. cit., str. 193-194, 282. 


\section{Vražji zmaj}

Predaje govore o pozojima na (sjevero)zapadu (Štrigova, Okrugli Vrh, Sveti Juraj na Bregu, Nedelišće), u središtu (Čakovec, Mihovljan, Ivanovec) i na istoku (Donji Mihaljevec, Donji Vidovec, Donja Dubrava) Međimurja.

Rep nedelišćanskog pozoja je u Vražjoj jami, a glava mu je pod crkvom sv. Jurja na Bregu. Čini se da je riječ o istoj Vražjoj jami kraj Gornjeg Hrašćana jer je Nedelišće od toga naselja udaljeno zračnom linijom oko 2,7 km. „Vu Vrožjoj jami je njegov rep, a pozoj je tak veliki kaj mo je glova tijam pod Svetim Jurjom na Brego" ${ }^{\text {"14 }}$.

Vraćajući se kući noću sa zabave, dvojica mladića prelazila su preko polja između Gornjeg Hrašćana i Pribislavca. Uplašili su se kad su vidjeli vragove kako plešu kraj jame. Mladići su ujutro za konopac privezali kamen i bacili ga u kaljužastu jamu. Nevjerojatno, jama nije imala dno! Od tada je njezino ime Vražja jama (kaz. M. Kovačić).

Pozoj je i pod zdencom u Okruglom Vrhu, udaljenom zračnom linijom od crkve sv. Jurja na Bregu oko 2,5 km, a od Nedelišća oko $7 \mathrm{~km}$. Štrigovskom pozoju jedna predaja glavu smješta pod baroknu crkvu sv. Jeronima, a rep pod barokiziranu župnu crkvu Marije Magdalene u Štrigovi. Druga predaja rep mu smješta pod crkvu sv. Jurja u Lopatincu ${ }^{15}$, no vjerojatnije je da se nalazi u Peklu, mikrotoponimu u podnožju crkve (kaz. Potočnik). I dok se vjerovalo da se vrag može pretvoriti u zmaja ${ }^{16}$ i sv. Iliju $^{17}$, u imenskoj osnovi praslavensko značenje te riječi je „,neprijatelj”, ${ }^{18}$. Pastiri, učeni grabancijaši i črnoškolci, mladi svećenici ili bezgrešni mladomisnici $^{19}$, dakle - učeno i za borbu protiv stare vjere ženskog predznaka

${ }^{14}$ F. Preložnjak, Nedelišće prije pedeset, sto i više godina, u: Nedelišće, ur. J. Buturac et al., Nedelišće 1993, str. 407.

${ }^{15}$ Na uzvišenom Glava selu kraj Železne Gore općine Štrigova žene su uzgajale kupus (kaz. M. Jakopić), a tu kulturu biljuk međimurske svadbe uzgajale su na Glavatišče i žene Donjeg Međimurja (M. Novak, op. cit., str. 24).

${ }^{16} \mathrm{~V}$. Jagić, Južnoslavenske narodne priče o grabancijašu dijaku i njihovo objašnjenje, u: Usmena književnost, ur. B. Brajenović, Zagreb 1971, str. 267.

${ }^{17}$ M. Novak, Tragovi hrvatske mitologije, Zagreb 2007, str. 53.

${ }^{18}$ A. Gluhak, Hrvatski etimološki rječnik, Zagreb 1993, str. 680.

${ }^{19}$ V. Jagić, op. cit., str. 265-283. 
spremno mlado svećenstvo ${ }^{20}$ može pomoću Biblije, čarobne knjige, štapa, zlatne uzde ili lančića ukrotiti prijeteće pozoje koji se u tlu pružaju i od nekadašnje mihovljanske gotičke crkve sv. Mihovila ili od današnjega franjevačkog samostana sv. Nikole nekadašnje župe sv. Mihovila do Staroga grada u Čakovcu te od vidovečke barokne crkve sv. Vida do pobočne kapele sv. Ane crkve sv. Mihovila na Legradskoj gori, nekad u župi Donji Vidovec, a danas u Mađarskoj ${ }^{21}$, nad Legradom - antičkim Carrodunumom - na ušću Mure u Dravu, ili do nekoga stočnog napajališta ${ }^{22}$.

\section{Vještica moriteljica}

Srodna ženska mitska bića su copernica, mora i štri(n)ga. Prvi naziv izveden je od njem. glagola zaubern ,čarati”, drugi od slav. moriti ,nasmrt mučiti”, a treći od lat. strix „sova krvopija” grč. podrijetla u vezi s alb.

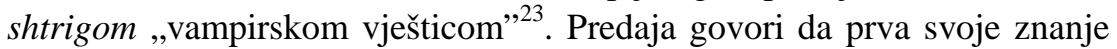
stječe učenjem, a treća nasljeđem, tj. rođenjem s repom i u crnoj placenti. Oči su im svijetle ili duginih boja $^{24}$, razroke su, urokljive, krivonoge, s papcima umjesto nogu ${ }^{25}$. Mogu se pretvoriti u miša, muhu, crnu kokoš, psa ili mačku. Uzrokuju nevrijeme, pošasti, bolest, piju krv, otimaju i jedu tuđu djecu. Ljubomorne su i zle zbog vlastite neplodnosti. Nemoralne su inkube i seksualne razvratnice ${ }^{26}$.

${ }^{20}$ D. Šantalab, Legenda o pozoju u dolini rijeke Bednje, Čakovec 2000, str. 186.

${ }^{21}$ M. Novak, op. cit., str. 252.

${ }^{22}$ F. Preložnjak, op. cit., str. 407; S. Petr-Marčec, Legende, u: Međimurje, turistički vodič Međimurske županije, ur. M. Purić Hranjec, Čakovec 2006, str. 202; Z. Bartolić, Dobravski portreti i skice, u: Općina i župa Donja Dubrava, ur. D. Feletar, Zagreb 2007, str. 226; kaz. K. i S. Potočnik.

${ }^{23}<$ www.en.wikipedia.org/wiki/Strigoi>; <www.en.wikipedia.org/wiki/Shtriga> [preuzeto: 3.08 .2012$]$.

${ }^{24}$ Z. Bašić, Sjeverozapadni vjetar - o vilenjacima i elementarnim bićima sjeverozapadnog dijela Medvednice pa do Samoborskog kraja, Zagreb 2011, str. 30.

${ }^{25}$ V. Spajić-Vrkaš, Tučepi - odrastanje u tradicijskoj kulturi Hrvata, Zagreb 1996, str. 120.

${ }^{26}$ B. Perić, T. Pletenac, Fantastična bića Istre i Kvarnera, Zagreb 2008, str. 18-25, $53-54,56$. 
Prema hebrejskom vjerovanju, Lilit je prva Adamova družica koja ga je napustila zbog nepristajanja vođenja ljubavi u podređenom položaju. Odletjela je u pustinju kraj Crvenog mora gdje se orodila s demonima. Srednjovjekovna legenda prikazuje ju kao opasnu noćnu zavodnicu muškaraca i sovoliku moriteljicu izvanbračne djece. Ime joj se izvodi od semitskog laila „noć” i novohebrejskog ,noćna sova”. Podsjeća na babilonsko-asirskoga ženskog demona lilitu $^{27}$. U hrvatskim predajama nalik su joj mitske more - djevojke bez stidnih dlaka ${ }^{28}$ koje noću sjedaju muškarcima na prsa, gnječe ih i isisavaju im snagu.

U Odiseji (III: 64 ff) Homer pjeva o naročitoj Telemahovoj kupki. Poznato je da su antički atletičari nakon slične kupke u tijelo utrljavali maslinovo ulje, udarajući se strigilom za bolju cirkulaciju ${ }^{29}$.

Kajkavska imenica dundača je „duga”, a glagol dunjkati „,udarati”, „grmjeti” i „strelati iz mužara na Jurjevo” (kaz. L. Krnjak). Ukrajinski dunduk, sunut i varjat je „luckast, priglup, udaren” (kaz. Orest Wilczynski). Hrvatska varjača „kutlača” možda se odnosi na boginjin kultni pribor. Tibetska varja je „munja, sveti kamen, tvrdi dijamant”,30 a Varjag je drugi naziv za Vikinga, pripadnika nordijskog naroda germanskog podrijetla. Kastavski munjen ${ }^{31}$, banijski i slavonski zalupan, šumast i tokmast „bez pameti”, šumonja „budala”, „,smušenjak” i smlata, šumnjak „osoba neuredne kose i odjeće" ${ }^{\text {"32 }}$ suodnose se s riječima smunja, smuda, ,žena sumnjiva morala" ${ }^{33}$ te s četirima bosanskim tokmakbabama s tokmakcima „staricama s batovima, maljevima” ${ }^{34}$ i s nadžak-babom „svadljivicom”, „oštrokondžom” koja bije jezikom kao nadžakom „,batom, maljem, 35 .

${ }^{27}$ Ibidem, str. 54-55.

${ }^{28}$ D. Orlić, Štorice od štrig $i$ štriguni, Zagreb-Sarajevo 2008, str. 34.

${ }^{29}$ H. Crosthwaite, A. de Grazia, KA - A Handbook of Mythology, New Jersey 1992, str. 187, <www.grazian-archive.com/quantavolution/QUANTAVOL/ka_docs> [preuzeto: 8.02.2012].

${ }^{30}$ P. Matthiessen, Snježni leopard, Zagreb 1997, str. 53.

${ }^{31}$ I. Jardas, Kastavština, ,Zbornik” br. 3, 1994 [1957], str. 397.

${ }^{32}$ K. Gašljević Tomić, Selo $i$ župa Viduševac, Zagreb 2010, str. 675, 679; M. Baboselac-Mišin, Oj, Bebrino, alaj si na glasu, Klakar 2002, str. 281, 282.

33 <www.govori.tripod.com/arvacki_ricnik.htm> [preuzeto: 7.10.2011].

${ }^{34}$ J. Vrkić, Hrvatske predaje, Zagreb 1995, str. 341, 442.

${ }^{35}$ B. Klaić, Rječnik stranih riječi $(A-\check{Z})$, Zagreb 1998, str. 923. 
U Lici su ,zločestu djecu” zvali poganom ${ }^{36}$. Te su riječi, čini se, u vezi sa slavenskom boginjom nepredvidljive i neukrotive ćudi, opasane trobojnim pojasom tkanicom koja u ruci drži razornu kuglastu munju ${ }^{37}$, istovjetnu ubojitoj kugli u kojoj leti ruska baba Jaga te jabukama kojima se igra hrvatska lepa Mara. S obzirom na hrvatske nazive babina tkanica, mavrica, Majke Božje trak, Boži pâsac... za „dúgu” koja isušuje, snažno potresuje (kaz. V. Novak) i vodi u onostrano ${ }^{38}$, slavenska božica nalik je grčkoj Iris, Herinoj glasnici.

\section{Tko je otimač blaga Majke Zemlje?}

Štrigova je važno povijesno središte Gornjeg Međimurja, antički Stridon kojem su sličnog nazivlja antička naselja Strigna u Istri i Sidron u Bukovici, Strigos u Grčkoj, Ponte Striglia, Strigara i Strigno u Italiji, Striggow u Njemačkoj, Strigailiškis u Litvi... Josip Bedeković-Komorski - pavlin, teolog i kroničar, u Bečkom Novom Mjestu objavio je 1752. Natale solum..., u kojem, između ostalog, dokazuje da se sv. Jeronim - teolog, filozof, jezikoslovac, prevoditelj Biblije na latinski jezik, papin tajnik i svetac ilirskog podrijetla - 340./347. rodio u Štrigovi, hodočasničkom središtu $\mathrm{s}$ iscjeljujućim izvorom ispod crkve sv. Jeronima Stridonske biskupije provincije Panonije ${ }^{39}$ koju su, odijeljenu od provincije Dalmacije starorimskim Norikom ${ }^{40}$ i rijekama Dravom i Dunavom, razorili Goti.

Naziv sela Strigova u općini Bosanska Kostajnica na sjeverozapadu Bosne i Hercegovine i istoimeni naziv brdske pritoke rijeke Une možda se

${ }^{36}$ J. Grčević, Kompolje, život i narodni običaji, Otočac 2000, str. 313.

${ }^{37}$ V. Belaj, op. cit., str. 189.

${ }^{38}$ I. Jardas, op. cit., str. 316.

${ }^{39}$ J. Bedeković-Komorski, Natale solum magni Ecclesiae doctoris Sancti Hieronymi in ruderibus Stridonis occultatum, probatorum nihilominus historicorum et geographicorum opinionibus, ad brevis Illyricanae chronologiae adjumento erutum (etc.), Bečko Novo Mjesto 1752 (idem, Rodno mjesto velikog crkvenog naučitelja sv. Jeronima skriveno pod ruševinama Stridona, objelodanjeno mišljenjima vrsnih povjesničara i zemljopisaca te uz pomoć kratke ilirske kronologije (etc.), prev. M. Rašić, u rukopisu).

${ }^{40}$ Veći dio područja današnje Austrije i Slovenije. 
suodnosi s kultom Terre Mater te s antičkim topionicama željeza i rudnicima željezne rude u tom $\mathrm{kraju}^{41}$.

Antički Rimljani isprva su štovali više sile numene, a potom i božanstva koja su preuzeli od pokorenih autohtonih naroda koji nisu kopali rudu i ispirali zlato. Rimski bog-kovač Vulkan ili Mulciber, srodan panonskom Sedatu, keltskom Sucelusu, grčkome šepavom Hefestu i etrurskom Sethlansu, štovao se na sušne Volkanalije 23.VIII. kada su mu na posvećenome mjestu žrtvovali ribe i u vatri talili neprijateljsko oružje. I kult Terre Mater častio se tamo gdje se iskorištavala željezna ruda.

$\mathrm{Na}$ području razvođa rijekâ Japre i Sane, poznatima po antičkim rudnicima željezne rude i ispiranju čuvenoga dalmatinskog zlata iz Vrbasovih nanosa, blizu nekadašnje granice između rimske provincije Panonije i Dalmacije kojem je Siscia bila upravno središte, pronađeno je devet žrtvenika posvećenih Terri Mater - personifikaciji poljodjelstva, obilja, blagostanja i rađanja, katkad i sa zmijom oko vrata. Ta je božica povezana sa starorimskim Tellusom, a možda i s grčkom Gejom ili s italskom Ceres, božanstvima klijanja ${ }^{42}$.

Antičkim Rimljanima strigoi je bio „besmrtni vampir”, a mormos „smrtni vampir”. Srodan je rumunjskome moroi $^{43}$. Rimski prirodopisac Plinije u djelu Historia naturalis piše ,da je nekoć neki konjanik kopljem probio baziliska $^{44}$, nakon čega je otrov kopljem donio smrt ne samo jahaču, nego i konju" 45 .

Gornjomeđimurska predaja govori o židovskom konjaniku Muraju koji se na bijelom konju uspinjao Murajovim bregom (kaz. M. Jakopić) ili Mohokosom, najvišom kotom Međimurske županije $(343,6 \mathrm{~m})$ čija je zemlja jednom vinogradaru u prošlom stoljeću iznjedrila slavensku bjelobrdsku ogrlicu. U životopisu židovske obitelji iz koje potječe hrvatski glazbenik i akademik Jurica Murai, nalazimo podatke o dolasku u Međi-

41 <www.bs.wikipedia.org/wiki/Bosanska_Kostajnica> [preuzeto: 8.02.2012].

${ }^{42}$ M. Sanader, Rasprave o rimskim kultovima, Zagreb 1999, str. 7-12, 43, 98-115, $121-127$.

43 <www.en.wikipedia.org/wiki/Moroi> [preuzeto: 3.08.2012].

${ }^{44}$ Prema kajkavskim predajama, pedalj dug bažiliškuš najopasnija je zmija koja palucanjem suši raslinje i ubija.

${ }^{45}$ B. Perić, T. Pletenac, op. cit., str. 56, 63. 
murje sredinom 19. st., o promjeni obiteljskog prezimena Mandl u toponimičko Murai, o gradnji ciglane u donjomeđimurskoj Belici i o kupnji gospodarskog imanja 1906. u Vučetincu. Je li novo obiteljsko prezime Juričin pradjed preuzeo iz pučke predaje oko obiteljskih posjeda?

Iako je Dubrovačko primorje na krajnjem jugu Hrvatske od Međimurja udaljeno $433 \mathrm{~km}$ zračne linije, ne pjevaju li možda njegovi tradicijski stihovi o mitskome lunarnom konjaniku-osvajaču?

Jedrio kum konja uz polje, / pred njim konjić, vila bijela. / Na konju sedlo, sve živo srebro, / u sedlu kume ko na gori sunce. / Pustio noge u hladne vode. / Nit' se voda muti, nit' se kum ljuti, / nego Boga moli da ga pomože $\mathrm{e}^{46}$.

Zaštitnik konjanika je sv. Juraj na bijelom konju koji djevojačkim pojasom kroti pozoja i probada ga kopljem ili mačem. U međimurskoj Donjoj Dubravi na Štefanje 26. XII. dotjerani bi mladići, jašući i utrkujući se na okićenim konjima, a prethodno zagazivši na njima u obližnju baru Periščicu, obilazili kuće s udavačama ${ }^{47}$.

Povezanosti pojma murai sa zagrobnim ${ }^{48}$ doprinosi i ime slavenske boginje Mor(an)e ili Mare, koje se izvodi od ie. *mer- ,smrviti”, „moriti",49, i oronim Mohokos - drugo ime za Murajev breg, u vezi sa slavenskom božicom Mokoš vjerojatno Mor(an)inom majkom čarobnicom ${ }^{50}$. Budući da su, prema kazivanju, žene na Cvetlin bregu blizu Mohokosa skupljale mahovinu za sesvetske cvjetne aranžmane, zanimljiva je teza koju mi je u lipnju 2012. usmeno priopćio Orest Wilczynski, ukrajinski grkokatolički svećenik i doktorand etnologije zagrebačkoga Filozofskog fakulteta, o pučkoj preoblici mitskoga antroponimičkog oronima Mokoš u toponim slaganjem mađarske riječi mohos „mahovina” i hrvatske riječi kositi.

${ }^{46}$ Lj. Marks, Križi lete po nebu, Dubrovnik 2011, str. 128.

${ }^{47}$ M. Novak, op. cit., str. 66-67.

${ }^{48}$ Nekropola Novoga egipatskog kraljevstva u Tebi na zapadnoj obali Nila je Qurnet Murai. <www.hr.wikipedia.org/wiki/Qurnet_Murai> [preuzeto: 23.06.2012].

${ }^{49}$ V. Belaj, op. cit., str. 231.

${ }^{50}$ Legenda o velškom čarobnjaku Merlinu, s imenskom osnovom *mer-, govori o njegovu ocu vragu i keltskom podrijetlu. <www.sh.wikipedia.org/wiki/Kelti> [preuzeto: 31.07.2012]. 


\section{Vrata prijelaza}

Suvremeni arheolog Andrej Pleterski uočio je da se u praslavenskoj mitološkoj interpretaciji krajobraza tri sakralne točke zamišljenog trokuta najčešće odnose kao najviša i najniža točka međusobno suprotstavljenih svjetova odijeljenih vodom. To su Perunova uzvisina i depresija Velike Majke, uz nešto nižu Jarilovu kotu ${ }^{51}$. No supostojanje dva para toponima povezanih sa zmijolikom Velikom Majkom/Veles ${ }^{52}$ i sinom Jarilom ili s njihovim mogućim epiklezama sv. Anom, sv. Helenom, Sv. Barbarom i sv. Nikolom te sv. Jurjem i sv. Mihovilom s jedne strane, a s Perunom i kćerkom Mor(an)om i njihovim epiklezama sv. Vidom, sv. Ilijom i sv. Urbanom te sv. Marijom s druge strane, upućuje i na traženje graničnog toponima. I doista, kazivač Martin oronim Železna gora u blizini Mohokosa pojašnjava železnim vratima koja je ,na početku gmajne, de je i po zimi zviral slankasti izvirek Kamen i de je fest vetar puhal, postavil nekši Židov" ${ }^{, 53}$, ne znajući zašto su sočnome stočnom pasištu uz šumu Lohovec na najnižoj koti Železne gore potrebna železna vrata. Kod Toplica Vučkovec/Sv. Martin 2,6 km sjevernije, mikrotoponim je Kamenor. Železna vrata podno Železne gore u općini Štrigova, nekadašnjega antičkog Stridona, baš kao i pjesnički motiv željeznih vrata na kulama iza planine ${ }^{54}$, možda su teritorijalna razdjelnica između neolitičkoga autohtonog stanovništva i antičkih doseljenika metalnog doba, a s tim u vezi i mjesto prijelaza iz onostranog u ovostrano.

${ }^{51}$ V. Belaj, Mit u prostoru, „Mošćenički zbornik” god. 3, br. 3, 2004, str. 18-33.

${ }^{52}$ U svjetlu suvremenih mitoloških razmatranja sveta je trijada Perun - Mokoš - Veles, no mislim da se radi o suodnošenju između majke Veles/Velež, oca Peruna i njihovih blizanaca Mare i Jarila.

${ }^{53}$ Predajama u kojima se naslućuje pretkršćanska starina kazivač pripisuje židovstvo, poistovjećujući starovjernost s vjerom dijela židovskih doseljenika koji su od 19. do polovice 20. st. doprinosili gospodarstvu Međimurja. Zanimljivo, jedna nabožna predaja o Lutherovu reformacijskome štovanju pozoja (I. Zvonar, Kajkavske usmene narodne pripovijetke, u: Usmena narodna književnost na tlu Međimurja II, ur. I. Zvonar, S. Hranjec, A. Strbad, Čakovec 1987, str. 301-302).

${ }^{54}$ Devet vrake železni motiv je jedne makedonske tradicijske pjesme (Original Motion Picture Soundtrack Music by Anastasia, film Before The Rain, režija Milčo Mančevski, Francuska 1994, br. 2). 
Brežuljkast krajolik Gornjeg Međimurja posljedica je otapanja ledenjaka zadnjega ledenog doba i u njegovu tlu nema željezne rude, ali se zna da je od 17. st. iz rijekâ Mure i Drave eksploatirano zlato, a u 19. i 20. st. nafta i ugljen. Rudnik ugljena djelovao je do sredine 20. st. i na Mohokosu (kaz. V. Novak). Možda se i na gornjomeđimurskim kultnim uzvisinama u antičko doba talilo neprijateljsko oružje radi uništavanja moći protivnika. Internetska potraga za srodnim oronimima podastire zanimljive podatke.

Kapela sv. Ane uzdiže se na Vashegyi/Željeznoj gori ${ }^{55}$ iznad Balatona/Blatnog jezera zapadnomađarske županije Zala. Oronim Gvozdeno $B r d o^{56}$ u istočnoj Srbiji, visok $560 \mathrm{~m}$, nedaleko je od zlatonosne rijeke Pek, grada Majdanpeka s rudnicima bakra i zlata još od predantičkog doba te od mezolitskoga i neolitskog arheološkog nalazišta Lepenski Vir. Páka ${ }^{57}$ je naselje na istoimenoj rječici u mađarskoj Zaladskoj županiji. Sličan je nazivu srpske rijeke $P e k$. Ime mu je slavenskog podrijetla i znači 'željezo'. Znakovitog je imena vrh Vestec na Železné hory ${ }^{58}$, visok $668 \mathrm{~m}$, na zapadu Češko-moravske visoravni. Krajobraz oživotvoruju rijeke Doubrava, Chrudimka i njihovi klanci (Krkanka, Strádovské peklo). Arheološki nalazi svjedoče o keltskom iskorištavanju rudnog bogatstva, na što upućuje i crvenkasto tlo. Srednjovjekovna arhitektura kulturno je nasljeđe cijelog područja, primjerice u mjestu Zlatý potok/Železná jama ${ }^{59}$. I u njemačkoj Rajni-Vestfaliji na 482,3 m uzdiže se Eisernhardt ${ }^{60}$, s rudnicima željezne rudače iz 19. st.

Današnjoj crkvi sv. Jeronima u Štrigovi prethodila je drvena kapelica u 15. st. razorena potresom. Naime pavlini su kao graditelji nove crkve u 18. st. na mjestu prethodne otkrili kameni temelj, kosti, hrastove ljesove i četverokutnu stelu s rutenskim natpisom ${ }^{61}$. O kultnoj važnosti tog mjesta

55 <www.vonyarcvashegy.utisugo.hu/latnivalok/szent-mihaly-domb-vonyarcvashegy282801.html> [preuzeto: 6.08.2012].

${ }^{56}<$ www.bs.wikipedia.org/wiki/Majdanpek> [preuzeto: 3.08.2012].

${ }^{57}<$ www.hu.wikipedia.org/wiki/P\%C3\%A1ka> [preuzeto: 3.08.2012].

${ }^{58}<$ www.raft.cz/cechy/zlaty_zelez.aspx $>$ [preuzeto:7.02.2012].

${ }^{59}<$ www.raft.cz/cechy/zlaty_zelez.aspx >; <www.zamky-hrady.eu/vylety-zelezne-horya-chrudimsko-detaily,40> [preuzeto: 8.02.2012].

${ }^{60}$ <www.de.wikipedia.org/wiki/Eisernhardt> [preuzeto: 8.02.2012].

61 <www.onecroatia.info/turisticke_atrakcije/crkva-sv-jeronima-strigova/> [preuzeto: 23.06.2012]. 
svjedoči i spomen na pavlinski samostan, dograđen kor i dva zvonika koji su uobičajeno sastavni dio katedrala, tlocrt crkve sličan glasovitoj bazilici sv. Petra u Rimu i freske Ivana Rangera iz istog stoljeća. Svetac trobrodne crkve Sv. Urbana, zaštitnik od gromova, upućuje na Peruna i Veles. Istoj općini pripadaju još dva oronima - Per(n)jak i Martinovski vrh te hidronimi Toplice i Morsko oko u kojem se zaklonjena obližnjom šumom Pekel davno utopila lijepa djevojka (kaz. F. Lovrec), oko kojeg se okupljaju vještice (kaz. A. Krištofić i G. Novak) i na koje podsjeća jezersko Morskiel Marinie oko/Rybie Jezioro ${ }^{62}$ u poljskim Tatrama, navodno povezano s Jadranskim morem ${ }^{63}$. O mogućoj vezi tih hidronima s urokljivim Marinim okom pisat ću zasebno.

\section{Zaključak}

Raščlambom izbora kazivanja i njihovom usporedbom s primjerima hrvatske usmene književnosti i s povijesno-kulturnim podacima o pojedinim toponimima, može se uočiti povijesni kontinuitet ženskih kultova u Gornjem Međimurju, od predantičkog kulta neolitičke Terre Mater, katkad predstavljene i pticom, pretkršćanske slavenske Mokoš i Mor(an)e i kršćanske Djevice Marije, čije su svete uzvisine obezvrijeđene i s vremenom zaboravljene ili su s trona svetih uzvisina svrgnute u onostrane paklene dubrave ${ }^{64}$, kamo su žene donedavno odnosile perje kokoši koja se objedovala na Fašnik „kaj ne bi išla kakšna nesnaga gori na breg” (kaz. M. Horvatić).

Uz životvorne rijeke Muru i Dravu i s onu stranu (železnih) vrata, uspostavlja se okruženje toponima novijih ratničkih antičkih ili slavenskih bogova i njihovih kršćanskih supstituta, primjerice istočno od Železne gore u Rimščaku i Sv. Urbanu, sjeveroistočno u naseljima u kojima se od 14. st. spominju četiri župne crkve posvećene sv. Martinu - gorljivome kršćanskom propovjedniku, biskupu i katoličkom svecu $^{65}-$ u Sv. Martinu na

62 <www.en.wikipedia.org/wiki/Morskie_Oko> [preuzeto: 13.05.2012].

63 <www.igougo.com/review-r1174616-Lake_Morskie_Oko._Eye_Of_The_Sea.html> [preuzeto: 13.05.2012]

${ }^{64}$ U župi Gornji Mihaljevec, nekad u sastavu župe Sv. Juraj na Bregu, smješteno je naselje (Gornja) Dubrava i ponirući potok Duša.

${ }^{65}$ A. Zaradija-Kiš, Sveti Martin - kult sveca i njegova tradicija u Hrvatskoj, Zagreb 2004 , str. 33. 
Muri, nekadašnjoj antičkoj vojnoj utvrdi Halicanum na cesti Poetovio Carnuntum, u Murskom Središću i u Podturenu ${ }^{66}$ te jugozapadno u Macin$\mathrm{cu}^{67}$. Unatoč tome opasnost od krivovjerja i dalje prijeti - lopatinečka crkva sv. Jurja, nedelišćanska crkva sv. Križa i grad Čakovec - možda antička Aquama, mogle bi, kažu predaje, propasti pod zemlju u vodeni bezdan, jer nema više srčanih progonitelja pozoja $\hat{a}^{68}$, mitskih zmajeva ili šumskih kornjača s rogovima (kaz. I. Hrženjak).

Pretkršćanska slavenska pobožnost na tlu Međimurja do sada nije tematizirana jer se slavenizacija sjevera današnje Hrvatske od kraja 6. st. povezuje s pokrštenim Slavenima. Sustavna arheološka i usporedna kulturno-povijesna istraživanja mogla bi iznjedriti nove spoznaje u korist pretkršćanskoga slavenskog mitiziranja hrvatskog tla ${ }^{69}$.

\section{Popis citiranih kazivača}

Zapis kazivanja Franje Lovreca, profesora glazbene kulture $i$ vinara iz Sv. Urbana, rođ. 1944. - zapisala Lidija Bajuk, VIII 2012. Ljubaznošću Jasne Lovrec (Sv. Urban). U vlasništvu Udruge Matapur, EKA FF i IEF (Zagreb).

Zapis kazivanja Irme Hrženjak, kućanice iz Kapelščaka, rođ. 1942. - zapisala Petra Novinšćak, III 2011.

Zapis kazivanja Julijane i Ivana Kavrana, umirovljenika iz Preloga - zapisala Smiljka Petr-Marčec, 1998. U vlasništvu Muzeja Međimurja (Čakovec).

Zapis kazivanja Lucije Krnjak, kućanice iz Mačkovca, rođ. 1940. u Dekanovcu - zapisala Lidija Bajuk, II 2011.

Zapis kazivanja Marije Kovačić, umirovljenice iz Pribislavca, rođ. 1940. - zapisala Maja Novosel, III 1996. U vlasništvu Lidije Bajuk (Zagreb).

Zapis kazivanja Martina Jakopića, građ. poduzetnik $i$ vinara iz Železne Gore, rođ. 1940. - zapisala Anita Brajinović, VIII 2012.

Zapis kazivanja Oresta Wilczynskog, grk.-kat. svećenika i doktoranda etnologije iz Lavova, rođ 1974. - zapisala Lidija Bajuk, V 2011.

${ }^{66}$ R. Horvat, Poviest Međimurja, Zagreb 1993 [1944], str. 33.

${ }^{67}$ V. Kalšan, Iz vjerskog života Međimurja, Čakovec 2003, str. 231.

${ }^{68}$ A. Dolenčić, Pretkršćanski ostaci i kršćanski elementi u međimurskim narodnim običajima i vjerovanjima u okviru hrvatskoga i inog folklora na kugli zemaljskoj, Rkp. NZ HAZU 120b 1952, str. 356, 358; A. Strbad, Rukoveti hrvatskoga narodnog blaga na međimurskoj kajkavštini, u: Usmena narodna književnost na tlu Međimurja II, str. 307.

${ }^{69}$ V. Belaj, op. cit., str. 73. 
Zvučni zapis kazivanja Anike Krištofić i Gabrijele Novak, kućanicâ iz Stanetinca, rođ. 1942. i 1943. - snimila Lidija Bajuk, IV 2011.

Zvučni zapis kazivanja Ivana Vožara, kovača-bravara iz Vrhovljana, rođ. 1935. u Brezovcu - snimile Martina i Kristina Vožar, IV 2011.

Zvučni zapis kazivanja Katarine i Stjepana Potočnika iz Zasadbrega, umirovljenika rođ. 1939. i 1938. - snimile Lidija Bajuk i Zvjezdana Jembrih, VII 2011.

Zvučni zapis kazivanja Margarete Horvatić, kućanice iz Zasadbrega, rođ. 1937. snimile Lidija Bajuk i Janja Kovač, III 2011.

Zvučni zapis kazivanja Marije Tuksar, kućanice iz Vratišinca, rođ. Kovačić 1939. snimila Lidija Bajuk, II 2007. U vlasništvu Lidije Bajuk (Zagreb).

Zvučni zapis kazivanja Terezije Farkaš, kućanice iz Malog Mihaljevca, rođ. Klobučarić 1932. - snimila Lidija Bajuk, II 2004. U vlasništvu Lidije Bajuk (Zagreb).

Zvučni zapis kazivanja Vere Novak, umirovljenice iz Zasadbrega, rođ. 1934. i 1940. snimila Lidija Bajuk, 27 IV 2012. 
